\title{
Prostate Cancer Incidence and Survival, by Stage and Race/Ethnicity - United States, 2001-2017
}

\author{
David A. Siegel, MD ${ }^{1}$; Mary Elizabeth O’Neil, MPH${ }^{1}$; Thomas B. Richards, MD ${ }^{1}$; Nicole F. Dowling, PhD ${ }^{1}$; Hannah K. Weir, PhD ${ }^{1}$
}

Among U.S. men, prostate cancer is the second leading cause of cancer-related death (1). Past studies documented decreasing incidence of prostate cancer overall since 2000 but increasing incidence of distant stage prostate cancer (i.e., signifying spread to parts of the body remote from the primary tumor) starting in $2010(2,3)$. Past studies described disparities in prostate cancer survival by stage, age, and race/ethnicity using data covering $\leq 80 \%$ of the U.S. population $(4,5)$. To provide recent data on incidence and survival of prostate cancer in the United States, CDC analyzed data from population-based cancer registries that contribute to U.S. Cancer Statistics (USCS). * Among 3.1 million new cases of prostate cancer recorded during 2003-2017, localized, regional, distant, and unknown stage prostate cancer accounted for $77 \%, 11 \%, 5 \%$, and $7 \%$ of cases, respectively, but the incidence of distant stage prostate cancer significantly increased during 2010-2017. During 2001-2016, 10-year relative survival for localized stage prostate cancer was $100 \%$. Overall, 5-year survival for distant stage prostate cancer improved from $28.7 \%$ during $2001-2005$ to $32.3 \%$ during 2011-2016; for the period 2001-2016, 5-year survival was highest among Asian/Pacific Islanders (API) (42.0\%), followed by Hispanics (37.2\%), American Indian/Alaska Natives (AI/AN) (32.2\%), Black men (31.6\%), and White men (29.1\%). Understanding incidence and survival differences by stage, race/ethnicity, and age can guide public health planning related to screening, treatment, and survivor care. Future research into differences by stage, race/ethnicity, and age could inform interventions aimed at improving disparities in outcomes.

Cases included males with malignant ${ }^{\dagger}$ prostate cancer ${ }^{\S}$ and excluded cases diagnosed by autopsy and death certificate only.

\footnotetext{
*https://www.cdc.gov/cancer/uscs.

${ }^{\dagger}$ https://www.cdc.gov/cancer/uscs/public-use/dictionary/behavior-codeICD-O-3.htm.

$\$$ https://seer.cancer.gov/siterecode/icdo3_dwhoheme/index.html.
}

Incidence data were from USCS during the period 2003-2017 and covered $100 \%$ of the U.S. population. Age-adjusted rates were expressed per 100,000 men.9 Trends in incidence were described using annual percent change (APC) and average annual percent change (AAPC) calculated by joinpoint regression. Statistically significant APC and AAPC were dif-

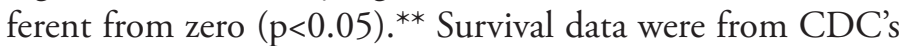
National Program of Cancer Registries (NPCR)-funded

I Rates were adjusted to the 2000 U.S. standard population.

** A maximum of two joinpoints were used to determine a change in direction of trend.

\section{INSIDE}

1481 Breast Cancer Survival Among Males by Race, Ethnicity, Age, Geographic Region, and Stage United States, 2007-2016

1485 Demographic Characteristics, Experiences, and Beliefs Associated with Hand Hygiene Among Adults During the COVID-19 Pandemic — United States, June 24-30, 2020

1492 An Outbreak of COVID-19 Associated with a Recreational Hockey Game — Florida, June 2020

1494 Transmission Dynamics by Age Group in COVID-19 Hotspot Counties — United States, AprilSeptember 2020

1497 Factors Influencing Risk for COVID-19 Exposure Among Young Adults Aged 18-23 Years Winnebago County, Wisconsin, March-July 2020

1503 QuickStats

Continuing Education examination available at https://www.cdc.gov/mmwr/mmwr_continuingEducation.html

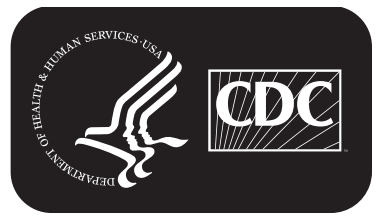

U.S. Department of Health and Human Services Centers for Disease Control and Prevention 
registries that conducted active case follow-up or linkage with CDC's National Death Index, and covered 94\% of the U.S. population. ${ }^{\dagger \dagger}$ Survival analysis included cases diagnosed during 2001-2016 with follow-up through December 31, 2016. Relative survival (cancer survival in the absence of other causes of death) was calculated ${ }^{\$}$ for 1,5 , and 10 years after diagnosis, using expected life tables stratified by age, sex, race/ethnicity, socioeconomic status, geographic location, and calendar year of diagnosis. 99 Differences between relative survival estimates were determined by comparing $95 \%$ confidence intervals (CIs), which allowed for an informal, conservative comparison of estimates. Differences in relative survival were noted when CIs did not overlap.

Incidence and survival were stratified by stage, age, year of diagnosis, and race/ethnicity. There were four categories for race (Black, White, AI/AN, and API) and one for ethnicity (Hispanic). Men categorized by race were all non-Hispanic. Men categorized as Hispanic might be of any race. Stage was defined using Summary Stage, the staging system used by the cancer surveillance community and defined with the following

\footnotetext{
$\dagger \dagger$ Registries met USCS publication criteria and included all U.S. states and the District of Columbia except for Connecticut, Hawaii, Indiana, Iowa, Kansas, and New Mexico.

$\$ \$$ The cohort method was used to estimate survival when all patients had a full 1,5 , and 10 years of follow-up. The complete method was used when not all patients had the full 5 or 10 years of follow-up for 5-year and 10-year survival time estimates. https://surveillance.cancer.gov/survival/cohort.html.

99 https://www.seer.cancer.gov.
}

categories: localized (tumor is confined to the organ of origin without extension beyond the primary organ), regional (direct extension of the tumor to adjacent organs or structures or spread to regional lymph nodes), distant (cancer has spread to parts of the body remote from the primary tumor), and unknown.**

During 2003-2017, a total of 3,087,800 new cases of prostate cancer were diagnosed in the United States (Table 1). Over this 15-year period, age-adjusted incidence decreased from 155 per 100,000 in 2003 to 105 in 2017 (Supplementary Table 1, https://stacks.cdc.gov/view/cdc/94592). During 2003-2017, incidence was highest for men aged 70-74 years (764) and Black men (202). Localized, regional, distant, and unknown stage prostate cancer accounted for $77 \%, 11 \%, 5 \%$, and $7 \%$ of total cases, respectively. The percentage of localized cases decreased from $78 \%$ in 2003 to $70 \%$ in 2017 , and distant cases increased from $4 \%$ in 2003 to $8 \%$ in 2017 . White men had lower percentages of distant $(5 \%)$ and unknown stage $(6 \%)$ prostate cancer than did any other race/ethnicity. The overall incidence of prostate cancer decreased during 2003-2017 (AAPC $=-2.5 \%$ ) but increased for cases diagnosed at distant stage $(\mathrm{AAPC}=2.2 \%)$. More specifically, the increase was observed during 2010-2017 (APC $=5.1 \%$ ) and began in 2011 or earlier, regardless of race/ethnicity.

\footnotetext{
*** Defined by merged Summary Stage. https://www.cdc.gov/cancer/uscs/ public-use/dictionary/merged-summary-stage.htm and https://training.seer. cancer.gov/collaborative/intro/systems_review.html.
}

The MMWR series of publications is published by the Center for Surveillance, Epidemiology, and Laboratory Services, Centers for Disease Control and Prevention (CDC), U.S. Department of Health and Human Services, Atlanta, GA 30329-4027.

Suggested citation: [Author names; first three, then et al., if more than six.] [Report title]. MMWR Morb Mortal Wkly Rep 2020;69:[inclusive page numbers]

\section{Centers for Disease Control and Prevention Robert R. Redfield, MD, Director Anne Schuchat, MD, Principal Deputy Director} Chesley L. Richards, MD, MPH, Deputy Director for Public Health Science and Surveillance Rebecca Bunnell, PhD, MEd, Director, Office of Science Arlene Greenspan, PhD, Acting Director, Office of Science Quality, Office of Science Michael F. Iademarco, MD, MPH, Director, Center for Surveillance, Epidemiology, and Laboratory Services MMWR Editorial and Production Staff (Weekly)

Charlotte K. Kent, PhD, MPH, Editor in Chief Jacqueline Gindler, MD, Editor

Paul Z. Siegel, MD, MPH, Guest Associate Editor Mary Dott, MD, MPH, Online Editor Terisa F. Rutledge, Managing Editor

Douglas W. Weatherwax, Lead Technical Writer-Editor

Glenn Damon, Soumya Dunworth, PhD,

Teresa M. Hood, MS, Narue J. Wright-Jegede, PhD Technical Writer-Editors

Michelle E. Bonds, MBA

Matthew L. Boulton, MD, MPH

Carolyn Brooks, ScD, MA Jay C. Butler, MD

Virginia A. Caine, MD
Martha F. Boyd, Lead Visual Information Specialist Alexander J. Gottardy, Maureen A. Leahy,

Julia C. Martinroe, Stephen R. Spriggs, Tong Yang, Visual Information Specialists

Quang M. Doan, MBA, Phyllis H. King,

Terraye M. Starr, Moua Yang, Information Technology Specialists

MMWR Editorial Board Timothy F. Jones, MD, Chairman Katherine Lyon Daniel, PhD Jonathan E. Fielding, MD, MPH, MBA David W. Fleming, MD William E. Halperin, MD, DrPH, MPH Jewel Mullen, MD, MPH, MPA Jeff Niederdeppe, PhD
Patricia Quinlisk, MD, MPH

Patrick L. Remington, MD, MPH Carlos Roig, MS, MA William Schaffner, MD

Morgan Bobb Swanson, BS 
TABLE 1. Age-adjusted incidence* of prostate cancer ${ }^{\dagger}$ and annual percent change (APC) and average APC (AAPC) in rates per 100,000 men, by selected characteristics - U.S. Cancer Statistics, United States, 2003-2017

\begin{tabular}{|c|c|c|c|c|c|c|c|c|c|}
\hline \multirow[b]{2}{*}{ Characteristic } & \multicolumn{2}{|c|}{ No., $\%$ of total, and rate } & \multirow{2}{*}{$\frac{\text { AAPC } 2003-2017^{\S}}{\operatorname{AAPC}(95 \% \mathrm{CI})}$} & \multicolumn{6}{|c|}{$\mathrm{APC}^{\S}$} \\
\hline & No. $(\%)^{\natural}$ & Rate $(95 \% \mathrm{Cl})$ & & Yrs & APC1 $(95 \%$ CI) & Yrs & APC2 $(95 \% \mathrm{Cl})$ & Yrs & APC3 $(95 \% \mathrm{Cl})$ \\
\hline Overall & $3,087,800(100)$ & $\begin{array}{c}128.4 \\
(128.2 \text { to } 128.5)\end{array}$ & $\begin{array}{c}-2.5 \\
(-4.1 \text { to }-0.9)^{* *}\end{array}$ & $2003-2007$ & $\begin{array}{c}2.0 \\
(-1.6 \text { to } 5.7)\end{array}$ & 2007-2014 & $\begin{array}{c}-6.6 \\
(-8.8 \text { to }-4.4)^{* *}\end{array}$ & 2014-2017 & $\begin{array}{c}1.6 \\
(-4.0 \text { to } 7.6)\end{array}$ \\
\hline \multicolumn{10}{|l|}{ Age group (yrs) } \\
\hline$\leq 49$ & $81,420(3)$ & $\begin{array}{c}5.2 \\
(5.1 \text { to } 5.2)\end{array}$ & $\begin{array}{c}-2.9 \\
(-4.0 \text { to }-1.7)^{* *}\end{array}$ & 2003-2009 & $\begin{array}{c}4.4 \\
(2.2 \text { to } 6.6)^{* *}\end{array}$ & 2009-2017 & $\begin{array}{c}-8.0 \\
(-9.5 \text { to }-6.4)^{* *}\end{array}$ & —†+ & - \\
\hline $50-54$ & $212,288(7)$ & $\begin{array}{c}134.5 \\
(133.9 \text { to } 135.0)\end{array}$ & $\begin{array}{c}-1.6 \\
(-3.7 \text { to } 0.6)\end{array}$ & 2003-2009 & $\begin{array}{c}2.7 \\
(0.2 \text { to } 5.2)^{* *}\end{array}$ & 2009-2014 & $\begin{array}{c}-7.4 \\
(-11.7 \text { to }-2.8)^{* *}\end{array}$ & 2014-2017 & $\begin{array}{c}-0.1 \\
(-7.8 \text { to } 8.3)\end{array}$ \\
\hline $55-59$ & $410,683(13)$ & $\begin{array}{c}288.0 \\
\text { (287.1 to } 288.9)\end{array}$ & $\begin{array}{c}-1.8 \\
(-3.6 \text { to } 0.0)\end{array}$ & $2003-2008$ & $\begin{array}{c}2.3 \\
(-0.7 \text { to } 5.4)\end{array}$ & 2008-2014 & $\begin{array}{c}-6.4 \\
(-9.2 \text { to }-3.6)^{* *}\end{array}$ & 2014-2017 & $\begin{array}{c}1.1 \\
(-5.7 \text { to } 8.3)\end{array}$ \\
\hline $60-64$ & $569,259(18)$ & $\begin{array}{c}484.7 \\
\text { (483.4 to } 485.9)\end{array}$ & $\begin{array}{c}-1.9 \\
(-3.7 \text { to }-0.1)^{* *}\end{array}$ & $2003-2008$ & $\begin{array}{c}1.9 \\
(-1.1 \text { to } 5.0)\end{array}$ & 2008-2014 & $\begin{array}{c}-6.9 \\
(-9.6 \text { to }-4.1)^{* *}\end{array}$ & 2014-2017 & $\begin{array}{c}2.2 \\
(-4.4 \text { to } 9.2)\end{array}$ \\
\hline $65-69$ & $658,449(21)$ & $\begin{array}{c}720.0 \\
\text { (718.3 to } 721.8)\end{array}$ & $\begin{array}{c}-2.0 \\
(-3.8 \text { to }-0.1)^{* *}\end{array}$ & $2003-2008$ & $\begin{array}{c}1.4 \\
(-1.8 \text { to } 4.8)\end{array}$ & 2008-2014 & $\begin{array}{c}-6.8 \\
(-9.8 \text { to }-3.8)^{* *}\end{array}$ & 2014-2017 & $\begin{array}{c}2.5 \\
(-4.3 \text { to } 9.8)\end{array}$ \\
\hline $70-74$ & $516,620(17)$ & $\begin{array}{c}764.0 \\
\text { (762.0 to } 766.1)\end{array}$ & $\begin{array}{c}-2.5 \\
(-4.4 \text { to }-0.6)^{* *}\end{array}$ & 2003-2007 & $\begin{array}{c}2.0 \\
(-2.4 \text { to } 6.5)\end{array}$ & 2007-2014 & $\begin{array}{c}-7.0 \\
(-9.2 \text { to }-4.6)^{* *}\end{array}$ & 2014-2017 & $\begin{array}{c}2.3 \\
(-4.8 \text { to } 9.9)\end{array}$ \\
\hline $75-79$ & $346,422(11)$ & $\begin{array}{c}693.6 \\
(691.3 \text { to } 695.9)\end{array}$ & $\begin{array}{c}-3.1 \\
(-4.9 \text { to }-1.3)^{* *}\end{array}$ & 2003-2007 & $\begin{array}{c}0.6 \\
(-3.1 \text { to } 4.5)\end{array}$ & 2007-2014 & $\begin{array}{c}-8.0 \\
(-10.2 \text { to }-5.9)^{* *}\end{array}$ & 2014-2017 & $\begin{array}{c}4.1 \\
(-3.1 \text { to } 11.7)\end{array}$ \\
\hline$\geq 80$ & $292,659(9)$ & $\begin{array}{c}473.1 \\
(471.4 \text { to } 474.8)\end{array}$ & $\begin{array}{c}-4.6 \\
(-5.9 \text { to }-3.2)^{* *}\end{array}$ & $2003-2007$ & $\begin{array}{c}-2.7 \\
(-5.7 \text { to } 0.4)\end{array}$ & 2007-2013 & $\begin{array}{c}-9.5 \\
(-11.7 \text { to }-7.2)^{* *}\end{array}$ & 2013-2017 & $\begin{array}{c}1.4 \\
(-2.4 \text { to } 5.2)\end{array}$ \\
\hline \multicolumn{10}{|l|}{ Race/Ethnicity ${ }^{\S \S}$} \\
\hline White & 2,296,805 (74) & $\begin{array}{c}122.2 \\
(122.0 \text { to } 122.3)\end{array}$ & $\begin{array}{c}-2.7 \\
(-4.7 \text { to }-0.5)^{* *}\end{array}$ & 2003-2007 & $\begin{array}{c}2.1 \\
(-2.5 \text { to } 7.0)\end{array}$ & 2007-2014 & $\begin{array}{c}-7.0 \\
(-9.4 \text { to }-4.6)^{* *}\end{array}$ & 2014-2017 & $\begin{array}{c}1.6 \\
(-6.7 \text { to } 10.7)\end{array}$ \\
\hline Black & $451,822(15)$ & $\begin{array}{c}202.3 \\
\text { (201.7 to } 203.0)\end{array}$ & $\begin{array}{c}-2.6 \\
(-3.9 \text { to }-1.2)^{* *}\end{array}$ & 2003-2009 & $\begin{array}{c}-0.5 \\
(-2.2 \text { to } 1.1)\end{array}$ & 2009-2014 & $\begin{array}{c}-6.6 \\
(-9.5 \text { to }-3.7)^{* *}\end{array}$ & 2014-2017 & $\begin{array}{c}0.4 \\
(-4.3 \text { to } 5.3)\end{array}$ \\
\hline $\mathrm{Al} / \mathrm{AN}$ & $12,232(0)$ & $\begin{array}{c}87.9 \\
(86.2 \text { to } 89.6)\end{array}$ & $\begin{array}{c}-3.4 \\
(-5.3 \text { to }-1.4)^{* *}\end{array}$ & 2003-2009 & $\begin{array}{c}-0.6 \\
(-3.1 \text { to } 1.8)\end{array}$ & 2009-2014 & $\begin{array}{c}-7.9 \\
(-11.8 \text { to }-3.8)^{* *}\end{array}$ & 2014-2017 & $\begin{array}{c}-1.1 \\
(-7.7 \text { to } 6.0)\end{array}$ \\
\hline API & $62,184(2)$ & $\begin{array}{c}67.2 \\
(66.6 \text { to } 67.7)\end{array}$ & $\begin{array}{c}-3.6 \\
(-6.5 \text { to }-0.6)^{* *}\end{array}$ & $2003-2011$ & $\begin{array}{c}-3.3 \\
(-4.8 \text { to }-1.7)^{* *}\end{array}$ & $2011-2014$ & $\begin{array}{c}-11.1 \\
(-23.5 \text { to } 3.3)\end{array}$ & 2014-2017 & $\begin{array}{c}3.6 \\
(-3.1 \text { to } 10.8)\end{array}$ \\
\hline Hispanic & $196,506(6)$ & $\begin{array}{c}106.0 \\
(105.5 \text { to } 106.5)\end{array}$ & $\begin{array}{c}-3.8 \\
(-4.9 \text { to }-2.6)^{* *}\end{array}$ & $2003-2008$ & $\begin{array}{c}-0.5 \\
(-2.5 \text { to } 1.5)\end{array}$ & 2008-2014 & $\begin{array}{c}-7.4 \\
(-9.1 \text { to }-5.7)^{* *}\end{array}$ & 2014-2017 & $\begin{array}{c}-1.5 \\
(-5.7 \text { to } 2.9)\end{array}$ \\
\hline \multicolumn{10}{|l|}{ Stage } \\
\hline Localized & $2,373,517(77)$ & $\begin{array}{c}98.1 \\
\text { (98.0 to } 98.3)\end{array}$ & $\begin{array}{c}-3.3 \\
(-5.1 \text { to }-1.4)^{* *}\end{array}$ & $2003-2007$ & $\begin{array}{c}3.1 \\
(-1.2 \text { to } 7.5)\end{array}$ & $2007-2014$ & $\begin{array}{c}-8.0 \\
(-10.1 \text { to }-5.9)^{* *}\end{array}$ & 2014-2017 & $\begin{array}{c}-0.1 \\
(-7.2 \text { to } 7.5)\end{array}$ \\
\hline Regional & $344,750(11)$ & $\begin{array}{c}13.5 \\
\text { (13.4 to } 13.5)\end{array}$ & $\begin{array}{c}0.2 \\
(-1.5 \text { to } 2.1)\end{array}$ & $2003-2007$ & $\begin{array}{c}3.3 \\
(-0.9 \text { to } 7.7)\end{array}$ & 2007-2013 & $\begin{array}{c}-3.2 \\
(-6.1 \text { to }-0.2)^{* *}\end{array}$ & 2013-2017 & $\begin{array}{c}2.5 \\
(-1.9 \text { to } 7.2)\end{array}$ \\
\hline Distant & $157,175(5)$ & $\begin{array}{c}7.2 \\
(7.1 \text { to } 7.2)\end{array}$ & $\begin{array}{c}2.2 \\
(1.7 \text { to } 2.7)^{* *}\end{array}$ & $2003-2010$ & $\begin{array}{c}-0.7 \\
(-1.5 \text { to } 0.2)\end{array}$ & 2010-2017 & $\begin{array}{c}5.1 \\
(4.3 \text { to } 5.8)^{* *}\end{array}$ & - & - \\
\hline Unknown & $212,358(7)$ & $\begin{array}{c}9.6 \\
(9.6 \text { to } 9.7)\end{array}$ & $\begin{array}{c}-2.8 \\
(-5.3 \text { to }-0.2)^{* *}\end{array}$ & $2003-2005$ & $\begin{array}{c}-16.5 \\
(-26.3 \text { to }-5.4)^{* *}\end{array}$ & 2005-2015 & $\begin{array}{c}-3.8 \\
(-5.4 \text { to }-2.1)^{* *}\end{array}$ & 2015-2017 & $\begin{array}{c}19.1 \\
(1.2 \text { to } 40.1)^{* *}\end{array}$ \\
\hline \multicolumn{10}{|c|}{ Stage by race/ethnicity } \\
\hline \multicolumn{10}{|l|}{ Localized } \\
\hline White & $1,782,452(78)$ & $\begin{array}{c}94.5 \\
\text { (94.3 to } 94.6)\end{array}$ & $\begin{array}{c}-3.4 \\
(-5.3 \text { to }-1.4)^{* *}\end{array}$ & 2003-2007 & $\begin{array}{c}3.1 \\
(-1.3 \text { to } 7.8)\end{array}$ & 2007-2014 & $\begin{array}{c}-8.4 \\
(-10.7 \text { to }-6.1)^{* *}\end{array}$ & 2014-2017 & $\begin{array}{c}0.5 \\
(-7.1 \text { to } 8.7)\end{array}$ \\
\hline Black & $349,321(77)$ & $\begin{array}{c}153.8 \\
(153.3 \text { to } 154.3)\end{array}$ & $\begin{array}{c}-2.9 \\
(-4.4 \text { to }-1.5)^{* *}\end{array}$ & $2003-2008$ & $\begin{array}{c}1.5 \\
(-1.0 \text { to } 4.0)\end{array}$ & 2008-2014 & $\begin{array}{c}-7.0 \\
(-9.2 \text { to }-4.8)^{* *}\end{array}$ & 2014-2017 & $\begin{array}{c}-1.7 \\
(-7.0 \text { to } 3.9)\end{array}$ \\
\hline $\mathrm{Al} / \mathrm{AN}$ & $8,818(72)$ & $\begin{array}{c}61.8 \\
(60.4 \text { to } 63.2)\end{array}$ & $\begin{array}{c}-3.9 \\
(-6.2-\text { to }-1.6)^{* *}\end{array}$ & $2003-2008$ & $\begin{array}{c}1.1 \\
(-3.0 \text { to } 5.3)\end{array}$ & 2008-2014 & $\begin{array}{c}-9.0 \\
(-12.5 \text { to }-5.3)^{* *}\end{array}$ & 2014-2017 & $\begin{array}{c}-1.6 \\
(-9.8 \text { to } 7.4)\end{array}$ \\
\hline API & $45,682(73)$ & $\begin{array}{c}48.9 \\
(48.5 \text { to } 49.4)\end{array}$ & $\begin{array}{c}-4.7 \\
(-7.5 \text { to }-1.9)^{* *}\end{array}$ & $2003-2007$ & $\begin{array}{c}-0.4 \\
(-7.4 \text { to } 7.1)\end{array}$ & 2007-2014 & $\begin{array}{c}-8.9 \\
(-12.2 \text { to }-5.5)^{* *}\end{array}$ & 2014-2017 & $\begin{array}{c}-0.2 \\
(-10.2 \text { to } 10.9)\end{array}$ \\
\hline Hispanic & $143,627(73)$ & $\begin{array}{c}76.3(75.8 \text { to } \\
76.7)\end{array}$ & $\begin{array}{c}-4.7 \\
(-5.9 \text { to }-3.6)^{* *}\end{array}$ & $2003-2008$ & $\begin{array}{c}0.0 \\
(-2.0 \text { to } 2.1)\end{array}$ & 2008-2014 & $\begin{array}{c}-8.8 \\
(-10.6 \text { to }-7.1)^{* *}\end{array}$ & 2014-2017 & $\begin{array}{c}-4.1 \\
(-8.4 \text { to } 0.4)\end{array}$ \\
\hline \multicolumn{10}{|l|}{ Regional } \\
\hline White & $267,155(12)$ & $\begin{array}{c}13.5 \\
(13.5 \text { to } 13.6)\end{array}$ & $\begin{array}{c}0.5 \\
(-1.5 \text { to } 2.5)\end{array}$ & $2003-2007$ & $\begin{array}{c}4.1 \\
(-0.6 \text { to } 9.0)\end{array}$ & 2007-2013 & $\begin{array}{c}-3.3 \\
(-6.5 \text { to }-0.1)^{* *}\end{array}$ & 2013-2017 & $\begin{array}{c}2.8 \\
(-2.1 \text { to } 7.9)\end{array}$ \\
\hline Black & $43,672(10)$ & $\begin{array}{c}17.5 \\
(17.3 \text { to } 17.6)\end{array}$ & $\begin{array}{c}-0.1 \\
(-2.1 \text { to } 2.0)\end{array}$ & $2003-2010$ & $\begin{array}{c}0.1 \\
(-1.6 \text { to } 1.8)\end{array}$ & 2010-2013 & $\begin{array}{c}-4.7 \\
(-14.0 \text { to } 5.5)\end{array}$ & 2013-2017 & $\begin{array}{c}3.3 \\
(0.0 \text { to } 6.6)^{* *}\end{array}$ \\
\hline $\mathrm{Al} / \mathrm{AN}$ & $1,412(12)$ & $\begin{array}{c}8.7 \\
(8.2 \text { to } 9.2)\end{array}$ & $\begin{array}{c}-0.7 \\
(-2.1 \text { to } 0.7)\end{array}$ & & & & & & \\
\hline API & $8,014(13)$ & $\begin{array}{c}7.8 \\
(7.6 \text { to } 8.0)\end{array}$ & $\begin{array}{c}0.9 \\
(-2.2 \text { to } 4.0)\end{array}$ & $2003-2011$ & $\begin{array}{c}1.1 \\
(-1.0 \text { to } 3.1)\end{array}$ & 2011-2014 & $\begin{array}{c}-8.1 \\
(-20.8 \text { to } 6.7)\end{array}$ & 2014-2017 & $\begin{array}{c}10.1 \\
(2.8 \text { to } 17.9)^{* *}\end{array}$ \\
\hline Hispanic & $21,853(11)$ & $\begin{array}{c}10.3 \\
(10.2 \text { to } 10.5)\end{array}$ & $\begin{array}{c}-1.4 \\
(-2.0 \text { to }-0.9)^{* *}\end{array}$ & 2003-2017 & $\begin{array}{c}-1.4 \\
(-2.0 \text { to }-0.9)^{* *}\end{array}$ & - & & - & \\
\hline
\end{tabular}

See table footnotes on the next page. 
Morbidity and Mortality Weekly Report

TABLE 1: (Continued) Age-adjusted incidence* of prostate cancer ${ }^{\dagger}$ and annual percent change (APC) and average APC (AAPC) in rates per 100,000 men, by selected characteristics - U.S. Cancer Statistics, United States, 2003-2017

\begin{tabular}{|c|c|c|c|c|c|c|c|c|c|}
\hline \multirow[b]{2}{*}{ Characteristic } & \multicolumn{2}{|c|}{ No., $\%$ of total, and rate } & \multirow{2}{*}{$\frac{\text { AAPC } 2003-2017^{\S}}{\operatorname{AAPC}(95 \% \mathrm{CI})}$} & \multicolumn{6}{|c|}{$\mathrm{APC}^{\S}$} \\
\hline & No. $(\%)^{\Upsilon}$ & Rate $(95 \% \mathrm{Cl})$ & & Yrs & APC1 $(95 \% \mathrm{Cl})$ & Yrs & APC2 $(95 \% \mathrm{Cl})$ & Yrs & APC3 $(95 \% \mathrm{Cl})$ \\
\hline \multicolumn{10}{|l|}{ Distant } \\
\hline White & $110,453(5)$ & $\begin{array}{c}6.4 \\
(6.3 \text { to } 6.4)\end{array}$ & $\begin{array}{c}2.7 \\
(2.1 \text { to } 3.2)^{* *}\end{array}$ & 2003-2010 & $\begin{array}{c}-0.2 \\
(-1.1 \text { to } 0.8)\end{array}$ & 2010-2017 & $\begin{array}{c}5.6 \\
(4.8 \text { to } 6.4)^{* *}\end{array}$ & - & - \\
\hline Black & $28,946(6)$ & $\begin{array}{c}15.1 \\
\text { (14.9 to } 15.2)\end{array}$ & $\begin{array}{c}0.1 \\
(-0.6 \text { to } 0.8)\end{array}$ & 2003-2011 & $\begin{array}{c}-2.4 \\
(-3.4 \text { to }-1.3)^{* *}\end{array}$ & 2011-2017 & $\begin{array}{c}3.5 \\
(2.2 \text { to } 4.8)^{* *}\end{array}$ & - & - \\
\hline $\mathrm{Al} / \mathrm{AN}$ & $911(7)$ & $\begin{array}{c}7.7 \\
\text { (7.1 to } 8.2 \text { ) }\end{array}$ & $\begin{array}{c}2.2 \\
(0.8 \text { to } 3.6)^{* *}\end{array}$ & & & & & & - \\
\hline API & $3,867(6)$ & $\begin{array}{c}4.7 \\
(4.6 \text { to } 4.9)\end{array}$ & $\begin{array}{c}1.7 \\
(-0.5 \text { to } 4.0)\end{array}$ & 2003-2006 & $\begin{array}{c}3.7 \\
(-4.4 \text { to } 12.5)\end{array}$ & $2006-2010$ & $\begin{array}{c}-5.0 \\
(-10.8 \text { to } 1.1)\end{array}$ & 2010-2017 & $\begin{array}{c}4.9 \\
(3.3 \text { to } 6.6)^{* *}\end{array}$ \\
\hline Hispanic & $12,275(6)$ & $\begin{array}{c}7.5 \\
\text { (7.4 to } 7.6)\end{array}$ & $\begin{array}{c}0.5 \\
(-0.3 \text { to } 1.3)\end{array}$ & 2003-2011 & $\begin{array}{c}-1.6 \\
(-2.9 \text { to }-0.4)^{* *}\end{array}$ & $2011-2017$ & $\begin{array}{c}3.4 \\
(2.0 \text { to } 4.8)^{* *}\end{array}$ & - & \\
\hline \multicolumn{10}{|l|}{ Unknown } \\
\hline White & $136,745(6)$ & $\begin{array}{c}7.8 \\
(7.8 \text { to } 7.9)\end{array}$ & $\begin{array}{c}-6.1 \\
(-9.0 \text { to }-3.1)^{* *}\end{array}$ & 2003-2005 & $\begin{array}{c}-19.2 \\
(-35.1 \text { to } 0.7)\end{array}$ & 2005-2017 & $\begin{array}{c}-3.8 \\
(-5.7 \text { to }-1.8)^{* *}\end{array}$ & - & - \\
\hline Black & $29,883(7)$ & $\begin{array}{c}16.0 \\
\text { (15.8 to } 16.2)\end{array}$ & $\begin{array}{c}-4.2 \\
(-5.7 \text { to }-2.7)^{* *}\end{array}$ & - & - & - & - & - & - \\
\hline $\mathrm{Al} / \mathrm{AN}$ & $1,091(9)$ & $\begin{array}{c}9.8 \\
(9.2 \text { to } 10.4)\end{array}$ & $\begin{array}{c}-6.0 \\
(-8.4 \text { to }-3.5)^{* *}\end{array}$ & - & - & - & - & - & - \\
\hline API & $4,621(7)$ & $\begin{array}{c}5.7 \\
\text { (5.5 to } 5.8 \text { ) }\end{array}$ & $\begin{array}{c}-2.0 \\
(-3.7 \text { to }-0.2)^{* *}\end{array}$ & - & - & - & - & - & - \\
\hline Hispanic & $18,751(10)$ & $\begin{array}{c}11.9 \\
\text { (11.7 to } 12.1)\end{array}$ & $\begin{array}{c}-4.2 \\
(-6.1 \text { to }-2.2)^{* *}\end{array}$ & - & - & - & - & - & - \\
\hline
\end{tabular}

Abbreviations: Al/AN = American Indian/Alaska Native; API = Asian/Pacific Islander; $\mathrm{Cl}=$ confidence interval.

* Incidence data are compiled from cancer registries that meet the U.S. Cancer Statistics publication criteria for the period 2003-2017 (covering $100 \%$ of the U.S. population). Characteristic values with other, missing, or blank results are not included. Rates are age-adjusted to the 2000 U.S. Standard population.

† Cases included International Classification of Diseases for Oncology, Third Edition malignant cancers only.

$\S$ Trends were considered to increase or decrease if $p<0.05$; otherwise trends were considered stable.

I Denominator for this column is 3,087,800, except for stage by race/ethnicity, where the denominator is the total number of cases for the respective race/ethnicity grouping ** $\mathrm{p}<0.05$.

t+ Trend described for the period 2003-2017 by previous APC columns.

$\S \S$ White, Black, Al/AN, and API men are non-Hispanic. Hispanic men might be of any race. Counts exclude unspecified or unknown race/ethnicity. Excludes 67,696 cases with non-Hispanic unknown race.

ใศ Defined by merged Summary Stage. https://www.cdc.gov/cancer/uscs/public-use/dictionary/merged-summary-stage.htm.

During 2001-2016, among 3,104,380 men with survival data, 5-year and 10-year relative survival was $97.6 \%$ and $97.2 \%$, respectively (Table 2 ). Men aged $\leq 49$ years and $\geq 80$ years had the lowest 10 -year relative survival $(95.6 \%$ and $82.7 \%$, respectively). For localized prostate cancer, 10 -year relative survival was $100 \%$. Ten-year relative survival for regional, distant, and unknown stage was $96.1 \%, 18.5 \%$, and $78.1 \%$, respectively. For distant stage prostate cancer, 10 -year relative survival was highest for ages $60-64$ years $(21.8 \%)$ and was $<20 \%$ for ages $<55$ and $\geq 70$ years.

Comparing 2001-2005 with 2011-2016, 5-year relative survival improved from $97.5 \%$ to $99.3 \%$ for regional stage and from $28.7 \%$ to $32.3 \%$ for distant stage prostate cancer (Table 3). During 20012016, 5-year survival for distant stage prostate cancer was highest among API (42.0\%), followed by Hispanics (37.2\%), AI/AN (32.2\%), Black men (31.6\%), and White men (29.1\%). Survival by race/ethnicity showed differences by age (Supplementary Table 2 , https://stacks.cdc.gov/view/cdc/94593). For unknown stage prostate cancer, 5-year survival was higher for Hispanic (84.4\%) and White men (82.8\%) than Black men (79.1\%).

\section{Discussion}

Although approximately three fourths of U.S. men with prostate cancer have localized stage at diagnosis, an increasing number and percentage of men have received diagnoses of distant stage prostate cancer. Survival with distant stage prostate cancer has improved, but fewer than one third of men survive 5 years after diagnosis. Survival disparities by age and race/ethnicity were noted for distant stage prostate cancer during all three periods (i.e., 2001-2005, 2006-2010, and 2011-2016) studied.

The U.S. Preventive Services Task Force (USPSTF) has issued several recommendations that discuss the possible benefits and harms of screening for prostate cancer using prostate-specific antigen (PSA). ${ }^{\dagger \dagger}$ In 2012, USPSTF concluded that the benefits of PSA-based screening do not outweigh the harms and

$i_{\dagger \dagger}$ Information about the benefits and harms of prostate cancer screening can be found at the CDC website. Digital rectal examination to screen for prostate cancer is not recommended by USPSTF because of lack of evidence of the benefits. https://www.cdc.gov/cancer/prostate/basic_info/benefits-harms. htm, https://www.uspreventiveservicestaskforce.org/uspstf/recommendation/ prostate-cancer-screening-2012, https://www.uspreventiveservicestaskforce. org/uspstf/recommendation/prostate-cancer-screening. 
TABLE 2. Relative survival of men with prostate cancer, 1, 5, and 10 years after diagnosis - United States, 2001-2016*

\begin{tabular}{|c|c|c|c|c|}
\hline Characteristic & No. & $\begin{array}{c}\text { 1-year relative survival } \\
\%(95 \% \mathrm{CI})\end{array}$ & $\begin{array}{c}\text { 5-year relative survival } \\
\%(95 \% \mathrm{CI})\end{array}$ & $\begin{array}{c}\text { 10-year relative survival } \\
\%(95 \% \mathrm{Cl})\end{array}$ \\
\hline Overall & $3,104,380$ & $99.0(98.9-99.0)$ & $97.6(97.5-97.6)$ & $97.2(97.2-97.3)$ \\
\hline \multicolumn{5}{|l|}{ Age group (yrs) } \\
\hline$\leq 49$ & 83,692 & $99.3(99.2-99.3)$ & $96.7(96.6-96.7)$ & $95.6(95.6-95.9)$ \\
\hline $50-54$ & 214,757 & 99.6 (99.5-99.6) & $97.8(97.6-97.8)$ & $96.9(96.9-97.1)$ \\
\hline $55-59$ & 407,302 & 99.7 (99.6-99.7) & 98.4 (98.3-98.4) & $98.0(98.0-98.1)$ \\
\hline $60-64$ & 559,872 & 99.7 (99.7-99.7) & $98.8(98.8-98.8)$ & $98.7(98.7-98.9)$ \\
\hline $65-69$ & 650,004 & 99.9 (99.9-99.9) & $99.6(99.5-99.6)$ & $99.5(99.5-99.7)$ \\
\hline $70-74$ & 525,876 & 99.8 (99.8-99.8) & 99.5 (99.4-99.5) & $99.4(99.4-99.6)$ \\
\hline $75-79$ & 361,735 & $99.1(99.0-99.1)$ & $98.4(98.2-98.4)$ & $97.9(97.9-98.3)$ \\
\hline$\geq 80$ & 301,315 & $92.1(92.0-92.1)$ & $84.6(84.2-84.6)$ & $82.7(82.7-83.5)$ \\
\hline \multicolumn{5}{|l|}{ Race/Ethnicity ${ }^{\dagger}$} \\
\hline White & $2,323,828$ & 99.1 (99.0-99.1) & 97.9 (97.9-97.9) & $97.8(97.8-97.9)$ \\
\hline Black & 459,665 & $98.4(98.4-98.4)$ & $95.6(95.4-95.6)$ & $93.5(93.5-93.8)$ \\
\hline $\mathrm{Al} / \mathrm{AN}$ & 11,983 & $98.2(97.7-98.2)$ & $95.7(94.7-95.7)$ & $93.4(93.4-95.0)$ \\
\hline API & 55,310 & 98.7 (98.6-98.7) & $95.1(94.8-95.1)$ & $92.0(92.0-92.6)$ \\
\hline Hispanic & 193,770 & $98.4(98.3-98.4)$ & $95.3(95.1-95.3)$ & $93.1(93.1-93.4)$ \\
\hline \multicolumn{5}{|l|}{ Stage $^{\S}$} \\
\hline Localized & $2,393,365$ & $100.0^{9}$ & 100.0 & 100.0 \\
\hline Regional & 328,421 & $100.0(100.0-100.0)$ & $98.6(98.5-98.6)$ & $96.1(96.1-96.4)$ \\
\hline Distant & 145,923 & $75.6(75.3-75.6)$ & $30.7(30.4-30.7)$ & $18.5(18.5-18.9)$ \\
\hline Unknown & 236,919 & $93.2(93.1-93.2)$ & $84.3(84.0-84.3)$ & $78.1(78.1-78.5)$ \\
\hline \multicolumn{5}{|c|}{ Stage by age group (yrs) } \\
\hline \multicolumn{5}{|l|}{ Localized } \\
\hline$\leq 49$ & 65,134 & $100.0(99.8-100.0)$ & 99.9 (99.7-99.9) & 99.8 (99.8-99.9) \\
\hline $50-54$ & 167,635 & 100.0 & 100.0 & 100.0 \\
\hline $55-59$ & 318,323 & 100.0 & 100.0 & 100.0 \\
\hline $60-64$ & 437,309 & 100.0 & 100.0 & 100.0 \\
\hline $65-69$ & 512,706 & 100.0 & 100.0 & 100.0 \\
\hline $70-74$ & 421,401 & 100.0 & 100.0 & 100.0 \\
\hline $75-79$ & 283,797 & 100.0 & 100.0 & 100.0 \\
\hline$\geq 80$ & 187,081 & $100.0(99.9-100.0)$ & $100.0(99.9-100.0)$ & $100.0(100.0-100.0)$ \\
\hline \multicolumn{5}{|l|}{ Regional } \\
\hline$\leq 49$ & 12,140 & 99.8 (99.6-99.8) & $97.0(96.5-97.0)$ & $92.6(92.6-93.4)$ \\
\hline $50-54$ & 32,016 & 100.0 & $97.9(97.6-97.9)$ & $94.1(94.1-94.6)$ \\
\hline $55-59$ & 58,398 & 100.0 & $99.0(98.7-99.0)$ & $95.9(95.9-96.4)$ \\
\hline $60-64$ & 76,162 & 100.0 & $100.0(91.2-100.0)$ & $97.8(97.8-98.2)$ \\
\hline $65-69$ & 77,433 & 100.0 & 100.0 & $99.9(99.9-100.0)$ \\
\hline $70-74$ & 42,562 & 100.0 & 100.0 & $99.6(99.6-100.0)$ \\
\hline $75-79$ & 17,034 & $99.3(98.8-99.3)$ & $94.2(93.1-94.2)$ & $90.4(90.4-92.3)$ \\
\hline$\geq 80$ & 12,678 & $90.7(89.9-90.7)$ & $70.8(69.0-70.8)$ & $64.4(64.4-67.3)$ \\
\hline
\end{tabular}

See table footnotes on the next page.

recommended against PSA-based screening for prostate cancer for men of all ages. This recommendation likely contributed to a decrease in overall reported prostate cancer incidence and might have contributed to an increase in the percentage and incidence of distant stage prostate cancer $(2,3)$. Despite decreasing incidence of localized stage prostate cancer, 130,658 to 190,570 new cases were diagnosed each year in the United States during 20032017. Even though 10-year survival for localized stage prostate cancer is $100 \%$, many of these patients need treatment, including surgery or radiation, often face long-term effects of their treatment (e.g., urinary incontinence and erectile dysfunction), and $\leq 6 \%$ progress to metastatic prostate cancer (6). Improvements in survival for distant stage prostate cancer might reflect changes in clinical management, which includes increased use of new agents and treatment innovations, such as new hormone and antibody therapies (6). Despite these improvements in survival, increases in distant stage prostate cancer incidence might have contributed to the plateauing of previously declining prostate cancer mortality during 2013-2017 (1,2).

Five-year survival for all stages combined was higher for White men than Black or Hispanic men. However, survival for distant stage prostate cancer was higher for Black than White men, which is different from a past study reporting higher survival for White men than Black men during 2001-2009, but with overlapping 95\% CIs (4). In addition, unknown stage prostate cancer represented a higher percentage of total cases (7\%) than distant stage prostate cancer $(5 \%)$, and survival for unknown stage prostate cancer was higher for Hispanic and White men than Black men. Men in the unknown stage category, who had a 5-year relative survival of $84.3 \%$, might include a mixture of situations, such as 
Morbidity and Mortality Weekly Report

TABLE 2. (Continued) Relative survival rate of men with prostate cancer, 1, 5, and 10 years after diagnosis - United States, 2001-2016*

\begin{tabular}{|c|c|c|c|c|}
\hline Characteristic & No. & $\begin{array}{c}\text { 1-year relative survival } \\
\%(95 \% \mathrm{CI})\end{array}$ & $\begin{array}{c}\text { 5-year relative survival } \\
\%(95 \% \mathrm{Cl})\end{array}$ & $\begin{array}{c}\text { 10-year relative survival } \\
\%(95 \% \mathrm{Cl})\end{array}$ \\
\hline \multicolumn{5}{|l|}{ Distant } \\
\hline$\leq 49$ & 3,083 & $84.9(83.6-84.9)$ & $31.1(29.2-31.1)$ & $19.0(19.0-20.9)$ \\
\hline $50-54$ & 6,488 & $85.4(84.5-85.4)$ & $32.7(31.3-32.7)$ & $19.1(19.1-20.5)$ \\
\hline $55-59$ & 12,607 & $84.3(83.6-84.3)$ & $35.5(34.5-35.5)$ & $20.8(20.8-21.9)$ \\
\hline $60-64$ & 18,268 & $83.2(82.6-83.2)$ & $35.1(34.2-35.1)$ & $21.8(21.8-22.8)$ \\
\hline $65-69$ & 21,311 & $82.4(81.8-82.4)$ & $36.2(35.3-36.2)$ & $21.2(21.2-22.1)$ \\
\hline $70-74$ & 21,066 & $77.9(77.3-77.9)$ & $33.3(32.5-33.3)$ & $19.8(19.8-20.9)$ \\
\hline $75-79$ & 21,299 & $73.4(72.8-73.4)$ & $29.9(29.0-29.9)$ & $18.5(18.5-19.6)$ \\
\hline$\geq 80$ & 41,810 & $63.3(62.8-63.3)$ & $22.5(21.8-22.5)$ & $14.6(14.6-15.8)$ \\
\hline \multicolumn{5}{|l|}{ Unknown } \\
\hline$\leq 49$ & 3,340 & $97.8(97.2-97.8)$ & $91.7(90.5-91.7)$ & $88.3(88.3-89.8)$ \\
\hline $50-54$ & 8,625 & $98.3(98.0-98.3)$ & $93.0(92.2-93.0)$ & $88.7(88.7-89.8)$ \\
\hline $55-59$ & 17,984 & $98.2(97.9-98.2)$ & $93.0(92.4-93.0)$ & $88.7(88.7-89.5)$ \\
\hline $60-64$ & 28,148 & $97.8(97.5-97.8)$ & $92.1(91.6-92.1)$ & $87.5(87.5-88.3)$ \\
\hline $65-69$ & 38,573 & $97.5(97.3-97.5)$ & $91.3(90.8-91.3)$ & $85.4(85.4-86.2)$ \\
\hline $70-74$ & 40,864 & $96.6(96.3-96.6)$ & $89.2(88.6-89.2)$ & $82.8(82.8-83.8)$ \\
\hline $75-79$ & 39,622 & $94.2(93.9-94.2)$ & $85.6(84.9-85.6)$ & $77.7(77.7-79.0)$ \\
\hline$\geq 80$ & 59,766 & $82.7(82.3-82.7)$ & $65.7(64.9-65.7)$ & $57.2(57.2-58.7)$ \\
\hline
\end{tabular}

Source: CDC's National Program of Cancer Registries, https://www.cdc.gov/cancer/npcr.

Abbreviations: Al/AN = American Indian/Alaska Native; API = Asian/Pacific Islander; $\mathrm{Cl}=$ confidence interval.

* Data were compiled from 45 population-based registries that cover approximately $94 \%$ of the US population. Counts for age and stage do not sum to the total because of multiple primaries methodology. When the relative survival is calculated stratified by a tumor or demographic characteristic, each cancer was included for patients diagnosed with multiple primary prostate cancers at the different category-levels.

+ White, Black, Al/AN, and API men are non-Hispanic. Hispanic men might be of any race. Counts exclude unspecified or unknown race/ethnicity. Excludes 59,824 cases of non-Hispanic unknown race.

$\S$ Percentage of total for localized, regional, distant, and unknown is $77 \%, 11 \%, 5 \%$, and $8 \%$, respectively.

" $\mathrm{Cl}$ could not be calculated.

men not healthy enough for a staging workup, situations where staging is not needed to guide treatment decisions, lack of access to care, or incomplete recording in the medical record (7). Past data suggest that social inequities by race contribute to worse outcomes for Black men than White men with prostate cancer (8). Survival based on distant stage and race/ethnicity might need to be interpreted in the context of the incidence and survival for other prostate cancer stages, as well as diagnostic procedures and social determinants of health such as access to care $(7,8)$.

Although survival by age varied by stage, survival was lowest for ages $>75$ years for regional, distant, and unknown stage prostate cancer. Lower survival for distant stage at age $>75$ years compared with younger ages might be secondary to more rapid development of resistant prostate cancer, reduced ability to receive available therapies, and impact of comorbidities (5). Ten-year survival was lower for men aged $\leq 49$ years compared with all ages except $\geq 80$ years. Prostate cancer incidence in men $\leq 49$ years has risen over the past 3 decades, and lower survival for this age group has been reported (9). Prostate cancer behavior, genetics, family history, and treatment patterns might affect prostate cancer incidence and survival patterns for men aged $\leq 49$ years (9).

The findings in this report are subject to least three limitations. First, prostate cancer cases missing from the dataset could result in an undercount of prostate cancer incidence, ${ }^{\mathbb{S} \$}$ and delays in

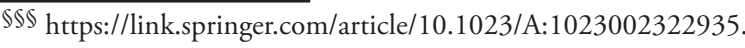

reporting could undercount incidence over the most recent years of the study (10). Second, Collaborative Cancer Staging coding, which was used from 2003 to 2015 to code stage data, might explain the lower numbers of unknown stage cases during those years. 999 Finally, confidence intervals could not be generated for all survival results that are rounded to $100.0 \%$, and values listed as $100.0 \%$ only mean that no excess deaths were observed.

In 2018, USPSTF issued a new recommendation stating that prostate cancer screening for men aged 55-69 years should be an individualized decision based on personal preferences when weighing the benefits and harms of screening,**** and several professional organizations have similarly recommended shared decision-making for men deciding about prostate cancer screening. ${ }^{\dagger \dagger \dagger}$ Understanding incidence and long-term survival by stage, race/ethnicity, and age could inform messaging related to the possible benefits and harms of prostate cancer screening and could guide public health planning related to treatment and survivor care. Further research is needed to examine how social determinants of health affect prostate

\footnotetext{
999 https://seer.cancer.gov/tools/collabstaging/.

**** https://www.uspreventiveservicestaskforce.org/uspstf/recommendation/ prostate-cancer-screening.

$\dagger \dagger \dagger$ https://www.auanet.org/guidelines/prostate-cancer-early-detectionguideline; https://www.cancer.org/cancer/prostate-cancer/detectiondiagnosis-staging/acs-recommendations.html; https://www.acpjournals. org/doi/10.7326/0003-4819-158-10-201305210-00633; and https://www. aafp.org/afp/2018/1015/od1.html.
} 
TABLE 3. Five-year relative survival for men with prostate cancer, by period and selected characteristics — United States, 2001-2016*

\begin{tabular}{|c|c|c|c|c|c|c|c|c|}
\hline \multirow[b]{2}{*}{ Characteristic } & \multicolumn{2}{|c|}{ 2001-2016 } & \multicolumn{2}{|c|}{ 2001-2005 } & \multicolumn{2}{|c|}{ 2006-2010 } & \multicolumn{2}{|c|}{ 2011-2016 } \\
\hline & No. & $\begin{array}{l}\text { Relative survival \% } \\
(95 \% \mathrm{Cl})\end{array}$ & No. & $\begin{array}{l}\text { Relative survival \% } \\
\quad(95 \% \mathrm{Cl})\end{array}$ & No. & $\begin{array}{l}\text { Relative survival \% } \\
(95 \% \mathrm{Cl})\end{array}$ & No. & $\begin{array}{l}\text { Relative survival \% } \\
(95 \% \mathrm{Cl})\end{array}$ \\
\hline Overall & $3,104,380$ & $97.6(97.5-97.6)$ & 965,748 & $97.3(97.2-97.4)$ & $1,052,255$ & $98.2(98.1-98.3)$ & $1,086,532$ & $97.2(97.1-97.3)$ \\
\hline \multicolumn{9}{|l|}{ Age group (yrs) } \\
\hline$\leq 49$ & 83,692 & $96.7(96.6-96.9)$ & 25,688 & $96.3(96.0-96.6)$ & 31,384 & $97.1(96.8-97.3)$ & 26,621 & $96.9(96.5-97.2)$ \\
\hline $50-54$ & 214,757 & 97.8 (97.6-97.9) & 63,318 & $97.8(97.6-98.0)$ & 76,549 & $97.9(97.7-98.1)$ & 74,893 & 97.4 (97.2-97.7) \\
\hline $55-59$ & 407,302 & $98.4(98.3-98.5)$ & 117,213 & $98.6(98.4-98.7)$ & 143,170 & $98.6(98.5-98.7)$ & 146,920 & 97.7 (97.5-97.9) \\
\hline $60-64$ & 559,872 & 98.8 (98.8-98.9) & 154,088 & $98.7(98.6-98.9)$ & 195,058 & $99.2(99.1-99.4)$ & 210,727 & 98.4 (98.2-98.6) \\
\hline $65-69$ & 650,004 & 99.6 (99.5-99.7) & 185,518 & 99.1 (98.9-99.3) & 213,975 & $99.9(99.7-100.0)$ & 250,514 & 99.5 (99.3-99.6) \\
\hline $70-74$ & 525,876 & 99.5 (99.4-99.6) & 175,220 & 99.1 (98.8-99.3) & 171,457 & $99.9(99.9-100.0)$ & 179,201 & $99.3(99.0-99.4)$ \\
\hline $75-79$ & 361,735 & $98.4(98.2-98.6)$ & 134,039 & $98.0(97.6-98.3)$ & 120,166 & $99.0(98.7-99.2)$ & 107,532 & 97.7 (97.4-98.0) \\
\hline$\geq 80$ & 301,315 & $84.6(84.2-84.9)$ & 110,671 & $85.7(85.2-86.3)$ & 100,506 & $86.9(86.3-87.4)$ & 90,144 & 79.7 (78.9-80.6) \\
\hline \multicolumn{9}{|l|}{ Race/Ethnicity ${ }^{\dagger}$} \\
\hline White & $2,323,828$ & 97.9 (97.9-98.0) & 752,786 & $97.8(97.7-97.9)$ & 792,482 & $98.6(98.5-98.6)$ & 778,682 & $97.3(97.2-97.5)$ \\
\hline Black & 459,665 & $95.6(95.4-95.7)$ & 130,818 & $94.8(94.6-95.1)$ & 152,416 & $96.1(95.9-96.3)$ & 176,445 & 95.7 (95.3-95.9) \\
\hline $\mathrm{Al} / \mathrm{AN}$ & 11,983 & $95.7(94.7-96.6)$ & 3,361 & $94.6(92.7-96.1)$ & 3,991 & $96.4(94.8-97.5)$ & 4,632 & $95.5(93.2-97.1)$ \\
\hline API & 55,310 & $95.1(94.8-95.5)$ & 14,865 & $95.4(94.7-96.0)$ & 18,207 & $95.5(94.9-96.0)$ & 22,241 & 94.7 (93.9-95.3) \\
\hline Hispanic & 193,770 & $95.3(95.1-95.5)$ & 52,951 & $94.9(94.5-95.2)$ & 64,680 & $96.0(95.7-96.3)$ & 76,154 & $95.2(94.8-95.6)$ \\
\hline \multicolumn{9}{|l|}{ Stage* } \\
\hline Localized & $2,393,365$ & $100.0^{\S}$ & 753,909 & $100.0^{\S}$ & 836,008 & $100.0^{\S}$ & 803,466 & $100.0^{\S}$ \\
\hline Regional & 328,421 & $98.6(98.5-98.7)$ & 87,320 & $97.5(97.3-97.8)$ & 106,635 & $99.0(98.8-99.2)$ & 134,467 & $99.3(98.9-99.5)^{\natural}$ \\
\hline Distant & 145,923 & $30.7(30.4-31.0)$ & 37,195 & $28.7(28.1-29.2)$ & 40,895 & $30.2(29.7-30.8)$ & 67,835 & $32.3(31.6-33.0)^{\curvearrowleft}$ \\
\hline Unknown & 236,919 & $84.3(84.0-84.5)$ & 87,357 & $83.0(82.6-83.4)$ & 68,748 & $84.2(83.7-84.6)$ & 80,818 & $86.7(86.1-87.2)^{\uparrow}$ \\
\hline \multicolumn{9}{|c|}{ Stage by race/ethnicity } \\
\hline \multicolumn{9}{|l|}{ Localized } \\
\hline White & $1,807,824$ & $100.0^{\S}$ & 592,631 & $100.0^{\S}$ & 634,465 & $100.0^{\S}$ & 580,741 & $100.0^{\S}$ \\
\hline Black & 354,643 & $100.0^{\S}$ & 99,964 & $100.0^{\S}$ & 121,260 & $100.0^{\S}$ & 133,420 & $100.0^{\S}$ \\
\hline $\mathrm{Al} / \mathrm{AN}$ & 8,626 & $100.0^{\S}$ & 2,477 & $99.9(97.3-100.0)$ & 2,960 & $100.0^{\S}$ & 3,189 & $100.0^{\S}$ \\
\hline API & 41,192 & $99.6(99.1-99.8)$ & 11,622 & $99.6(98.1-99.9)$ & 13,940 & $99.6(98.6-99.9)$ & 15,631 & $99.8(97.4-100.0)$ \\
\hline Hispanic & 142,007 & $100.0^{\S}$ & 39,557 & $100.0^{\S}$ & 48,798 & $100.0^{\S}$ & 53,655 & $100.0^{\S}$ \\
\hline \multicolumn{9}{|l|}{ Regional } \\
\hline White & 254,394 & $98.6(98.5-98.8)$ & 68,723 & $97.5(97.2-97.7)$ & 83,382 & $99.0(98.7-99.2)$ & 102,290 & $99.4(99.0-99.7)^{\natural}$ \\
\hline Black & 42,843 & $98.8(98.3-99.1)$ & 11,027 & $97.9(96.9-98.5)$ & 13,494 & $99.3(98.3-99.7)$ & 18,322 & $98.9(97.7-99.5)$ \\
\hline $\mathrm{Al} / \mathrm{AN}$ & 1,366 & $98.2(93.2-99.5)$ & 354 & 97.3 (87.8-99.4) & 431 & $98.5(82.2-99.9)$ & 581 & 97.5 (79.3-99.7) \\
\hline API & 6,671 & $97.4(96.5-98.1)$ & 1,491 & $97.1(95.0-98.4)$ & 2,091 & $97.9(96.3-98.9)$ & 3,089 & $96.9(94.7-98.2)$ \\
\hline Hispanic & 20,794 & $97.5(97.0-98.0)$ & 5,145 & $96.8(95.7-97.7)$ & 6,424 & $97.9(96.9-98.5)$ & 9,225 & $98.0(96.7-98.8)$ \\
\hline \multicolumn{9}{|l|}{ Distant } \\
\hline White & 101,621 & $29.1(28.7-29.5)$ & 25,864 & $27.2(26.6-27.9)$ & 28,392 & $28.5(27.9-29.1)$ & 47,367 & $30.8(29.9-31.6)^{\natural}$ \\
\hline Black & 28,330 & $31.6(30.9-32.3)$ & 7,718 & $29.9(28.6-31.1)$ & 8,047 & $31.0(29.9-32.2)$ & 12,565 & $33.3(31.8-34.9)^{\uparrow}$ \\
\hline $\mathrm{Al} / \mathrm{AN}$ & 796 & $32.2(27.8-36.8)$ & 180 & $29.0(21.6-36.8)$ & 219 & $27.9(21.3-34.8)$ & 397 & $39.0(30.4-47.4)$ \\
\hline API & 3,153 & $42.0(39.6-44.3)$ & 650 & $38.1(33.9-42.3)$ & 853 & $43.3(39.5-47.0)$ & 1,650 & $41.5(36.8-46.1)$ \\
\hline Hispanic & 11,418 & $37.2(36.1-38.4)$ & 2,655 & $35.3(33.3-37.4)$ & 3,213 & $37.4(35.5-39.3)$ & 5,550 & $37.5(35.2-39.9)$ \\
\hline \multicolumn{9}{|l|}{ Unknown } \\
\hline White & 160,180 & $82.8(82.5-83.2)$ & 65,593 & $83.3(82.8-83.8)$ & 46,266 & $82.0(81.4-82.5)$ & 48,322 & 83.0 (82.2-83.8) \\
\hline Black & 33,879 & 79.1 (78.3-79.8) & 12,113 & $78.3(77.1-79.5)$ & 9,619 & $78.8(77.5-80.0)$ & 12,148 & $80.9(79.3-82.4)$ \\
\hline $\mathrm{Al} / \mathrm{AN}$ & 1,196 & $82.2(78.1-85.7)$ & 350 & $76.9(69.4-82.8)$ & 381 & $84.6(77.6-89.6)$ & 465 & $84.1(74.8-90.3)$ \\
\hline API & 4,298 & $82.7(80.9-84.4)$ & 1,102 & $82.0(78.5-84.9)$ & 1,323 & $81.1(78.0-83.7)$ & 1,873 & $85.4(81.5-88.5)$ \\
\hline Hispanic & 19,572 & $84.4(83.5-85.2)$ & 5,598 & $80.6(79.0-82.1)$ & 6,249 & $86.5(85.1-87.7)$ & 7,727 & $85.8(83.9-87.6)^{\natural}$ \\
\hline
\end{tabular}

Source: CDC's National Program of Cancer Registries. https://www.cdc.gov/cancer/npcr.

Abbreviations: Al/AN = American Indian/Alaska Native; API = Asian/Pacific Islander; $\mathrm{Cl}=$ confidence interval.

* Data were compiled from 45 population-based registries that cover approximately $94 \%$ of the U.S. population. Counts for age and stage do not sum to the total because of multiple primaries methodology. When the relative survival is calculated stratified by a tumor or demographic characteristic, each cancer was included for patients diagnosed with multiple primary prostate cancers at the different category levels.

† White, Black, Al/AN, and API men are non-Hispanic. Hispanic men might be of any race. Counts exclude unspecified or unknown race/ethnicity. Excludes 59,824 cases of non-Hispanic unknown race.

$\S \mathrm{Cl}$ could not be calculated.

I Indicates nonoverlapping 95\% Cls when comparing 2001-2005 with 2011-2016. 


\section{Summary}

What is already known about this topic?

Among U.S. men, prostate cancer is the second leading cause of cancer-related death. The incidence of distant stage prostate cancer (signifying spread to parts of the body remote from the primary tumor) has increased since 2010.

What is added by this report?

Additional years of data show continued increases in the incidence of distant stage prostate cancer in the United States. The percentage of distant stage prostate cancer increased from $4 \%$ in 2003 to $8 \%$ in 2017 . Five-year survival for distant stage prostate cancer improved from $28.7 \%$ during 2001-2005 to $32.3 \%$ during 2011-2016; for the period 2001-2016, 5-year survival was highest among Asian/Pacific Islanders (42.0\%), followed by Hispanics (37.2\%), American Indian/Alaska Natives (32.2\%), Black men (31.6\%), and White men (29.1\%).

What are the implications for public health?

Understanding the disease trends of distant stage prostate cancer and disparities in prostate cancer survival by stage, race/ ethnicity, and age can guide public health planning related to screening, treatment, and survivor care.

cancer diagnosis and treatment; findings should inform interventions to decrease disparities in outcomes.

\section{Acknowledgments}

Reda J. Wilson, Division of Cancer Prevention and Control, National Center for Chronic Disease Prevention and Health Promotion, CDC; state and regional cancer registry and health department personnel.

Corresponding author: David A. Siegel, dsiegel@cdc.gov, 770-488-4426.

${ }^{1}$ Division of Cancer Prevention and Control, National Center for Chronic

Disease Prevention and Health Promotion, CDC.
All authors have completed and submitted the International Committee of Medical Journal Editors form for disclosure of potential conflicts of interest. No potential conflicts of interest were disclosed.

\section{References}

1. Henley SJ, Ward EM, Scott S, et al. Annual report to the nation on the status of cancer, part I: national cancer statistics. Cancer 2020;126:2225-49. https://doi.org/10.1002/cncr.32802

2. Negoita S, Feuer EJ, Mariotto A, et al. Annual report to the nation on the status of cancer, part II: recent changes in prostate cancer trends and disease characteristics. Cancer 2018;124:2801-14. https://doi. org $/ 10.1002 /$ cncr.31549

3. Jemal A, Culp MB, Ma J, Islami F, Fedewa SA. Prostate cancer incidence 5 years after US Preventive Services Task Force recommendations against screening. J Natl Cancer Inst 2020. Epub May 20, 2020. https://doi. org/10.1093/jnci/djaa068

4. Steele CB, Li J, Huang B, Weir HK. Prostate cancer survival in the United States by race and stage (2001-2009): findings from the CONCORD-2 study. Cancer 2017;123(Suppl 24):5160-77. https:// doi.org/10.1002/cncr.31026

5. Bernard B, Burnett C, Sweeney CJ, Rider JR, Sridhar SS. Impact of age at diagnosis of de novo metastatic prostate cancer on survival. Cancer 2020;126:986-93. https://doi.org/10.1002/cncr.32630

6. Litwin MS, Tan HJ. The diagnosis and treatment of prostate cancer: a review. JAMA 2017;317:2532-42. https://doi.org/10.1001/ jama.2017.7248

7. Luo Q, Yu XQ, Smith DP, et al. Cancer-related hospitalisations and 'unknown' stage prostate cancer: a population-based record linkage study. BMJ Open 2017;7:e014259. https://doi.org/10.1136/ bmjopen-2016-014259

8. Riviere P, Luterstein E, Kumar A, et al. Survival of African American and non-Hispanic white men with prostate cancer in an equal-access health care system. Cancer 2020;126:1683-90. https://doi.org/10.1002/ cncr.32666

9. Salinas CA, Tsodikov A, Ishak-Howard M, Cooney KA. Prostate cancer in young men: an important clinical entity. Nat Rev Urol 2014;11:317-23. https://doi.org/10.1038/nrurol.2014.91

10. Clegg LX, Feuer EJ, Midthune DN, Fay MP, Hankey BF. Impact of reporting delay and reporting error on cancer incidence rates and trends. J Natl Cancer Inst 2002;94:1537-45. https://doi.org/10.1093/ jnci/94.20.1537 